\title{
Vagal Nerve Stimulation Effects on Generalized-Partial Seizures and Medication in Adult Drug-Resistant Epilepsy Patients
}

\author{
Selcuk OZDOGAN, Raziye Handan NURHAT ${ }^{2}$, Ali Haluk DUZKALIR ${ }^{3}$, Deniz YUCE ${ }^{4}$, Hakan SABUNCUOGLU², \\ Zeki GOKCIL ${ }^{5}$, Ersin ERDOGAN² \\ ${ }^{1}$ Yeditepe University, School of Medicine, Department of Neurosurgery, Istanbul, Turkey \\ 2Ufuk University, School of Medicine, Department of Neurosurgery, Ankara, Turkey \\ ${ }^{3}$ Mus State Hospital, Mus, Turkey \\ ${ }^{4}$ Hacettepe University, School of Medicine, Department of Preventive Oncology, Ankara, Turkey \\ ${ }^{5}$ Gulhane Military Medical Academy, Department of Neurology, Ankara, Turkey \\ This study was presented as poster presentation at the $30^{\text {th }}$ International Epilepsy Congress in Montreal, Canada, $23-27$ June, 2013.
}

\section{ABSTRACT}

AIM: The aim of this study was to find out if vagal nerve stimulation (VNS) affect the generalized-partial seizure count and medical treatment in adult drug resistant epilepsy patients.

MATERIAL and METHODS: Twenty adult patients who were diagnosed with drug-resistant epilepsy were investigated retrospectively for vagal nerve stimulator implantation between 2001 and 2010 at the Neurosurgery Departments of Ufuk University and Gulhane Military Medical Academy. The effects of vagal nerve stimulation on generalized-partial seizures and medical treatment was scored and if a significant difference was found, a comparison was made by Wilcoxon Signed Ranks test and Pairwise. For all the group analyses, the statistical significant rank was accepted as a $p$ value $<0.05$. Bonferroni correction was made when it was needed during pairwise comparisons.

RESULTS: VNS significantly decreased the scores of generalized-partial seizures. There was no decrease in the doses of antiepileptic drugs and the medical treatment was resumed as before the implantation. The results were correlated with the relevant literature.

CONCLUSION: VNS is an alternative treatment option for drug resistant epilepsy for patients who are not ideal candidates for surgery or are not healed after epilepsy surgery.

KEYWORDS: Drug resistant epilepsy, Vagus nerve stimulation, Epilepsy surgery

\section{INTRODUCTION}

Epilepsy is a common neurologic disorder, characterized by abnormal electrical discharges in the brain, resulting in seizures, possibly with involuntary movements of the extremities and/ or loss of consciousness $(5,8,15)$. Approximately $1 / 3$ of the patients cannot be cured even they try all of the medical treatments $(2,6)$. For this reason, vagal nerve stimulation (VNS) is an alternative treatment when medical treatment and epilepsy surgery is insufficient $(3,14,29,30)$. After animal studies, the first human implantation for treating epilepsy occurred in 1988, which was followed by U.S. Food and Drug Administration (FDA) approval in 1997 for the adjunctive use in treatment resistant focal epilepsies $(4,7,31,32,38,39)$. 
Ozdogan S. et al: Vagal Nerve Stimulation

In our study, the first implantation of VNS was made in 2001. The aim of this study was to find out if VNS affects the generalized-partial seizure count and medical treatment in adult drug-resistant epilepsy patients (27).

\section{MATERIAL and METHODS}

Twenty adult patients, who were diagnosed drug-resistant epilepsy between 2001 and 2010, and who underwent VNS implantation based on the decision of the Epilepsy Surgery Council, were analyzed retrospectively. The data of the patients were gathered from the hospital databases of Ufuk University Faculty of Medicine and Gulhane Military Medical Academy.

The Council chose the patients in 3 phases. After a detailed anamnesis, non-invasive tests like electroencephalography (EEG), video-EEG, magnetic resonance imaging (MRI), positron emission tomography (PET) and neuropsychiatric tests were performed. If more detailed tests were needed, we performed invasive EEG with deep or strip electrodes. The last phase was to discuss the type of surgery through hemispherectomy, callosotomy, temporal lobectomy, hippocampectomy, amygdalectomy or palliative surgeries like VNS. All surgeries were performed by the senior neurosurgeon (EE).

The demographics of the patients were presented by descriptive statistics. Generalized and partial seizure frequencies were recorded in 5 discrete periods, and these were compared by Friedman non-parametric analysis of variances. When a significant result was found by the Friedman test, the Wilcoxon Signed Ranks test was then used for pairwise comparisons between groups. Differences in measurements were visually presented with box-plot graphics. An alpha error level of $5 \%$ was considered as a Type 1 error limit for statistical significance, and the Bonferroni correction was calculated for determining statistically significant $p$ values in pairwise comparisons.

\section{- RESULTS}

This study included 20 patients (12 men, 8 women). The mean age was $29.9 \pm 10.96$ (range 19 to 65 ) years. When frequencies of generalized seizures were compared between pre-operative and post-operative $2^{\text {nd }}, 6^{\text {th }}, 12^{\text {th }}$, and $24^{\text {th }}$ months, a statistically significant difference was noted $(p=0.038)$, (Table I).

The reduction rates of frequencies in generalized seizures after VNS implantation were $60.4 \%$ reduction in $2^{\text {nd }}$ month, $70.6 \%$ reduction in $6^{\text {th }}$ month, and $84.9 \%$ reduction in $12^{\text {th }}$ month.

Only 11 of the patients were followed-up for over 2 years, and these patients showed a $89.3 \%$ reduction when compared with the first group (Table II). There was a statistically significant difference between partial seizure frequencies at the preoperative and postoperative $2^{\text {nd }}, 6^{\text {th }}, 12^{\text {th }}$, and $24^{\text {th }}$ months ( $p<0.001$, Table III). Partial seizures were decreased $57.8 \%$ at $2^{\text {nd }}$ month, $59.2 \%$ at $6^{\text {th }}$ month, $54.9 \%$ at $12^{\text {th }}$ month after VNS implantation. Only 11 patients were followed up for 2 years, and these patients had a reduction of $75.9 \%$ in partial seizures (Table IV). Analyses of medical treatment between the preoperative and postoperative period revealed that there were no changes in medications. Patients neither changed nor decreased their antiepileptic drug doses.

Briefly, VNS implantation significantly decreased the frequencies of generalized and partial seizures. Additionally, medical treatment did not change after VNS implantation.

\section{- DISCUSSION}

The mechanism of VNS therapy is complicated. Henry (18) and Nemeroff et al.(26) tried to find out the mechanism and they saw that VNS causes increased synaptic activity in the thalamus and thalamo-cortical projection pathways as a result of increased arousal and a decreased synchrony of synaptic activities at cortical regions. VNS leads to intermittently increased synaptic activities in the components of the central autonomic system, such as the insula and the hypothalamus (3). There is decreased synaptic activity in components of the limbic system. Finally, VNS therapy results in intermittently increased release of norepinephrine and serotonin over widespread cerebral regions. $(18,25,26,28)$.

We have some limitations in our study. First this is a retrospective study and we could reach a limited number of patients for the long-term follow up period. In addition, we cannot compare our results with the placebo surgery trials where one must deactivate the VNS, because of the ethical problems. The same limitations can be seen in other studies in the literature as well. The earlier studies reported that the decrease rate of seizures with the use of VNS changes from $40 \%$ to $90 \%$ in the literature. Our results are between the rates of $54.9 \%$ and $89.3 \%$ which are similar to the previously reported rates. Amar et al. (1) compared the reduction in seizure burden following VNS insertion of 3822 patients without a prior history of epilepsy surgery with that of 921 patients with persistent seizures following cranial surgery. In patients without prior epilepsy surgery, $62 \%$ had $\geq 50 \%$ reduction in seizures and $27 \%$ had $\geq 90 \%$ reduction in seizure burden. Patients who failed epilepsy surgery had a poorer response to VNS therapy as $55 \%$ of patients had $\geq 50 \%$ and $17 \%$ had $\geq 90 \%$ reduction in seizure frequency (1). Similarly, Labar et al. examined 1407 patients and reported no difference in VNS efficacy between patients who remained on a stable antiepileptic drug regimen and those who required more medications or changed medications (20).

DeGiorgio et al. investigated 195 patients with generalized and partial TRE and showed a median reduction in seizure burden of $40 \%$ at a follow-up duration of 12 months (9). Vonck et al. analyzed the efficiency of VNS in 118 adults and pediatric patients with TRE who received VNS therapy at least 6 months. At a mean follow-up duration of 33 months, they reported a mean reduction of $55 \%$ in seizures of the patients. The results were similar in adolescents and children who were under 13 years (36). Elliot et al. analyzed 436 patients and inspected that seizure control $\geq 90 \%$ was achieved in 90 patients $(22.5 \%), \geq 75 \%$ seizure control in 162 patients (40.5\%), $\geq 50 \%$ improvement in 255 patients $(63.75 \%)$, and $50 \%$ improvement in 145 patients $(36.25 \%)(12,13)$. Probably 
Table I: Frequencies of Generalized Seizures in the Preoperative and Postoperative Periods

\begin{tabular}{|c|c|c|c|c|c|c|c|}
\hline Period & Mean & SD & Median & Minimum & Maximum & Range & $\mathbf{p}$ \\
\hline Preop & 25.5 & 33.11 & 8.5 & 2 & 94 & 92 & \multirow{5}{*}{0.038} \\
\hline VNS $2^{\text {nd }}$ Month & 10.1 & 15.13 & 3.5 & 1 & 61 & 60 & \\
\hline VNS $6^{\text {th }}$ Month & 7.5 & 14.35 & 1.5 & 0 & 60 & 60 & \\
\hline VNS $12^{\text {th }}$ Month & 3.83 & 4.23 & 1.5 & 0 & 15 & 15 & \\
\hline VNS $24^{\text {th }}$ Month & 2.73 & 2.49 & 2 & 0 & 8 & 8 & \\
\hline
\end{tabular}

Table II: Changes in Frequencies of Generalized Seizures Between the Preoperative Period and Postoperative $2^{\text {nd }}, 6^{\text {th }}, 12^{\text {th }}$, and $24^{\text {th }}$ Months

\begin{tabular}{cccc}
\hline $\begin{array}{c}\text { Before VNS - } 2 \text { months after } \\
\text { VNS (\% change) }\end{array}$ & $\begin{array}{c}\text { Before VNS - } \mathbf{6} \text { months after } \\
\text { VNS (\% change) }\end{array}$ & $\begin{array}{c}\text { Before VNS - } \mathbf{1} \text { years after } \\
\text { VNS (\% change) }\end{array}$ & $\begin{array}{c}\text { Before VNS - } 2 \text { years after } \\
\text { VNS (\% change) }\end{array}$ \\
\hline 60.4 & 70.6 & 84.9 & 89.3 \\
\hline
\end{tabular}

Table III: Frequencies of Partial Seizures at the Preoperative and Postoperative Periods

\begin{tabular}{cccccccc}
\hline Period & Mean & SD & Median & Minimum & Maximum & Range & p \\
\hline Preop & 128.35 & 70.34 & 124.5 & 4 & 250 & 246 \\
\hline VNS 2 $^{\text {nd }}$ Month & 54.05 & 45.21 & 31 & 4 & 151 & 147 \\
\hline VNS 6 $^{\text {th }}$ Month & 52.4 & 42.87 & 31 & 1 & 150 & 149 & $<0.001$ \\
\hline VNS 12 $^{\text {th }}$ Month & 57.78 & 53.14 & 31 & 0 & 180 & 180 \\
\hline VNS 24 $^{\text {th }}$ Month & 30.91 & 25.87 & 30 & 0 & 90 & 90 \\
\hline
\end{tabular}

Table IV: Changes in Frequencies of Partial Seizures Between Preoperative Period and Postoperative $2^{\text {nd }}, 6^{\text {th }}, 12^{\text {th }}$, and $24^{\text {th }}$ Months

\begin{tabular}{cccc}
$\begin{array}{c}\text { Before VNS } \mathbf{- 2} \text { months after } \\
\text { VNS }(\% \text { change) }\end{array}$ & $\begin{array}{c}\text { Before VNS }-\mathbf{6} \text { months after } \\
\text { VNS }(\% \text { change) }\end{array}$ & $\begin{array}{c}\text { Before VNS }-\mathbf{1} \text { years after } \\
\text { VNS }(\% \text { change) }\end{array}$ & $\begin{array}{c}\text { Before VNS }-2 \text { years after } \\
\text { VNS }(\% \text { change })\end{array}$ \\
\hline 57.8 & 59.2 & 54.9 & 75.9 \\
\hline
\end{tabular}

the highest reduction in seizure count was reported by Spanaki et al. This study also included only patients with follow up longer than 5 years. They reported an overall seizure reduction of $72 \%$ (34). At 5 years of follow-up after beginning the stimulation, Kuba et al. reported $64.4 \%$ of patients were responders whose $15.5 \%$ experienced $90 \%$ seizure reduction, and $5.5 \%$ were seizure-free (19). Tatum et al. showed that seizure duration and postictal recovery improved in 15 of 21 patients after VNS implantation (35). Similarly, McHugh et al. reported improvement in ictal and/or postictal severity in 19 of 48 patients (24). Moreover, Tatum et al. reported a reduction in the number and dosage of antiepileptic drugs after VNS (35). Wheeler et al. used Engel Classification in their study of 189 patients. Six percent of patients had a class I outcome which means seizure-free, $13 \%$ a class II outcome (almost seizurefree), $49 \%$ a class III outcome (worth while improvement) and $32 \%$ had a class IV outcome (no improvement) (37). Similar to our study, De Herdt et al. reported no changes in medical treatment after VNS implantation (10). There are many studies made for usage of VNS from different modalities. In addition to a reduction in seizure frequency, Tatum et al. and McHugh et al. found that seizure duration and postictal recovery improved as a result of VNS implantation $(24,35)$.

Several studies reported the efficacy of VNS in different disorders except epilepsy such as Lennox-Gastaut syndrome, migraine, depression, Alzheimer disease, multiple sclerosis for postural cerebellar tremor and dysphagia, eating disorders like bulimia nervosa and Tourette syndrome $(11,16,17,21,22,23,33)$. It seems VNS will be a treatment modality for many diseases in the future.

\section{CONCLUSION}

Implantation of VNS decreases the scores of generalizedpartial seizures. Our results were correlated with the relevant literature. VNS implantation is a featured alternative treatment option for epilepsy drug resistant patients who cannot accept surgery or are not healed after epilepsy surgery. 


\section{- REFERENCES}

1. Amar AP, Apuzzo ML, Liu CY: Vagus nerve stimulation therapy after failed cranial surgery for intractable epilepsy: Results from the vagus nerve stimulation therapy. Patient Outcome Registry. Neurosurgery 55: 1086-93, 2004

2. Asconapé JJ: The selection of antiepileptic drugs for the treatment of epilepsy in children and adults. Neurol Clin 28(4):843-852, 2010

3. Beekwilder JP, Beems T: Overview of the clinical applications of vagus nerve stimulation. J Clin Neurophysiol 27(2):130-138, 2010

4. Ben-Menachem E, Manon-Espaillat R, Ristanovic R, Wilder BJ, Stefan H, Mirza W, Tarver WB, Wernicke JF: Vagus nerve stimulation for treatment of partial seizures: 1. A controlled study of effect on seizures. First International Vagus Nerve Stimulation Study Group. Epilepsia 35:616-626, 1994

5. Bilir E, Leventoğlu A: Epilepsi. Chapter 34. Ankara: Nobel Tıp Kitapevi, 2008:397-408 (In Turkish)

6. Smith BJ, Cole AJ: Management of epilepsy in drug-resistant patients. CNS Spectr 15(1 Suppl 2):1, 3-7, 2010

7. Coffey LL, Reith MBA, Chen NH, Mishra PK, Jobe PC: Amygdala kindling of forebrain seizures and the occurrence of brainstem seizures in genetically epilepsy-prone rats. Epilepsia 37(2):188-197, 1996

8. Proposal for revised classification of epilepsies and epileptic syndromes. Commission classification and terminology of the international league against epilepsy. Epilepsia 30(4):388-399, 1989

9. DeGiorgio CM, Schachter SC, Handforth A, Salinsky M, Thompson J, Uthman B, Reed R, Collins S, Tecoma E, Morris GL, Vaughn B, Naritoku DK, Henry T, Labar D, Gilmartin R, Labiner D, Osorio I, Ristanovic R, Jones J, Murphy J, Ney G, Wheless J, Lewis P, Heck C: Prospective long-term study of vagus nerve stimulation for the treatment of refractory seizures. Epilepsia 41:1195-1200, 2000

10. De Herdt V, Boon P, Ceulemans B, Hauman H, Lagae L, Legros B, Sadzot B, Van Bogaert P, van Rijckevorsel K, Verhelst $\mathrm{H}$, Vonck K: Vagus nerve stimulation for refractory epilepsy: A Belgian multicenter study. Eur J Paediatr Neurol 11:261-269, 2007

11. Diamond A, Kenney C, Jankovic J: Effect of vagal nerve stimulation in a case of Tourette's syndrome and complex partial epilepsy. Mov Disord 21:1273-1275, 2006

12. Elliott RE, Morsi A, Kalhorn SP, Marcus J, Sellin J, Kang M, Silverberg A, Rivera E, Geller E, Carlson C, Devinsky O, Doyle WK: Vagus nerve stimulation in 436 consecutive patients with treatment-resistant epilepsy: Long-term outcomes and predictors of response. Epilepsy Behav 20(1):57-63, 2011

13. Elliott RE, Morsi A, Tanweer O, Grobelny B, Geller E, Carlson C, Devinsky O, Doyle WK: Efficacy of vagus nerve stimulation over time: Review of 65 consecutive patients with treatmentresistant epilepsy treated with VNS $>10$ years. Epilepsy Behav 20(3):478-483, 2011

14. Erdem A: Epilepsi Cerrahisi. Temel Nöroşirurji (Basic Neurosurgery). Ankara: Turkish Neurosurgical Society, 1998: 309-320 (In Turkish)
15. Erdoğan E, Gökçil Z: Epilepsi Cerrahisi. Temel Nöroşirurji (Basic Neurosurgery). Ankara:Turkish Neurosurgical Society, 2010: 2039-2060

16. Faris PL, Hofbauer RD, Daughters R, Vandenlangenberg E, Iversen L, Goodale RL, Maxwell R, Eckert ED, Hartman BK: De-stabilization of the positive vago-vagal reflex in bulimia nervosa. Physiol Behav 94: 136-153, 2008

17. George MS, Rush AJ, Marangell LB, Sackeim HA, Brannan SK, Davis SM, Howland R, Kling MA, Moreno F, Rittberg B, Dunner D, Schwartz T, Carpenter L, Burke M, Ninan P, Goodnick P: A one-year comparison of vagus nerve stimulation with treatment as usual for treatment-resistant depression. Biol Psychiatry 58: 364-373, 2005

18. Henry TR: Therapeutic mechanisms of vagus nerve stimulation. Neurology 59: 3-14, 2002

19. Kuba R, Brázdil M, Kalina M, Procházka T, Hovorka J, Nezádal T, Hadac J, Brozová K, Sebronová V, Komárek V, Marusic P, Oslejsková H, Zárubová J, Rektor I: Vagus nerve stimulation: Longitudinal follow-up of patients treated for 5 years. Seizure 18(4):269-274, 2009

20. Labar D, Murphy J, Tecoma E: Vagus nerve stimulation for medication-resistant generalized epilepsy. E04 VNS Study Group. Neurology 52:1510- 1512, 1999

21. Lenaerts ME, Oommen KJ, Couch JR, Skaggs V: Can vagus nerve stimulation help migraine? Cephalalgia 28:392-395, 2008

22. Majoie HJ, Berfelo MW, Aldenkamp AP, Renier WO, Kessels AG: Vagus nerve stimulation in patients with catastrophic childhood epilepsy, a 2-year follow-up study. Seizure 14: 1018, 2005

23. Marrosu F, Maleci A, Cocco E, Puligheddu M, Barberini L, Marrosu MG: Vagal nerve stimulation improves cerebellar tremor and dysphagia in multiple sclerosis. Mult Scler 13: $1200-1202,2007$

24. McHugh JC, Singh HW, Phillips J, Murphy K, Doherty $\mathrm{CP}$, Delanty $\mathrm{N}$ : Outcome measurement after vagal nerve stimulation therapy: Proposal of a new classification. Epilepsia 48: 375-378, 2007

25. Müller K, Fabó D, Entz L, Kelemen A, Halász P, Rásonyi G, Eross L: Outcome of vagus nerve stimulation for epilepsy in Budapest. Epilepsia 51 Suppl 3:98- 101, 2010

26. Nemeroff CB, Mayberg HS, Krahl SE, McNamara J, Frazer A, Henry TR, George MS, Charney DS, Brannan SK: VNS therapy in treatment-resistant depression: Clinical evidence and putative neurobiological mechanisms. Neuropsychopharmacology 31: 1345-1355, 2006

27. Ozdoğan S: Ilaca dirençli erişkin epilepsi hastalarında vagus siniri stimülatörü kullanılmasının jeneralize-parsiyel nöbet sayıları ve medikal tedavi üzerine etkileri (Uzmanlık Tezi). Ankara: Ufuk Universitesi, 2011:1-67 (In Turkish)

28. Penry JK, Dean JC: Prevention of intractable partial seizures by intermittent vagal stimulation in humans: Preliminary results. Epilepsia 31 Suppl 2: S40-43, 1990

29. Ramsay RE, Uthman BM, Augustinsson LE, Upton AR, Naritoku D, Willis J, Treig T, Barolat G, Wernicke JF: Vagus nerve stimulation for treatment of partial seizures: 2. Safety, side effects, and tolerability. First International Vagus Nerve Stimulation Study Group. Epilepsia 35(3):627-636, 1994 
30. Rutecki P: Anatomical, physiological and the oretical basis for the antiepileptic efect of vagus nerve stimulation. Epilepsia 31 Suppl 2:S1-6, 1990

31. Schachter SC, Saper CB: Vagus nerve stimulation. Epilepsia 39(7):677-686, 1998

32. Schuele SU, Lüders HO: Intractable epilepsy: Management and therapeutic alternatives. Lancet Neurol 7(6):514-524, 2008

33. Sjogren MJ, Hellstrom PT, Jonsson MA, Runnerstam M, Silander HC, Ben-Menachem E: Cognition-enhancing effect of vagus nerve stimulation in patients with Alzheimer's disease: A pilot study. J Clin Psychiatry 63:972-980, 2002

34. Spanaki MV, Allen LS, Mueller WM, Morris III GL: Vagus nerve stimulation therapy: 5-year or greater outcome at a university based epilepsy center. Seizure 13:587-590, 2004

35. Tatum WO, Johnson KD, Goff S, Ferreira JA, Vale FL: Vagus nerve stimulation and drug reduction. Neurology 56:561-563, 2001
36. Vonck K, Thadani V, Gilbert K, Dedeurwaerdere S, De Groote L, De Herdt V, Goossens L, Gossiaux F, Achten E, Thiery E, Vingerhoets G, Van Roost D, Caemaert J, De Reuck J, Roberts $D$, Williamson $P$, Boon $P$ : Vagus nerve stimulation for refractory epilepsy: A transatlantic experience. J Clin Neurophysiol 21: 283-289, 2004

37. Wheeler M, De Herdt V, Vonck K, Gilbert K, Manem S, Mackenzie T, Jobst B, Roberts D, Williamson P, Van Roost $D$, Boon P, Thadani V: Efficacy of vagus nerve stimulation for refractory epilepsy among patient subgroups: A re-analysis using the Engel classification. Seizure 20(4): 331-335, 2011

38. Woodbury DM, Woodbury JW: Effects of vagal stimulation on experimentally induced seizures in rats. Epilepsia 31 Suppl 2: S7-S19, 1990

39. Zabara J: Inhibition of experimental seizures in canines by repetitive vagal stimulation. Epilepsia 33:1005-1012, 1992 